\title{
Evaluation Index System of Construction Industry Development under the High-quality Development
}

\author{
Xizhen $\mathrm{Gao}^{1}$, Huimin Wang ${ }^{1, *}$ \\ ${ }^{1}$ Tianjin University of Technology, School of Management, 300384 Tianjin, China
}

\begin{abstract}
Under the background of the new era, it is of great strategic significance for the construction industry and the national economy to study and promote the construction industry. With the five development concepts as the guiding ideology, the system of development of construction industry is constructed in order to provide reference for promoting the the develop high quality of construction industry in China.
\end{abstract}

\section{Introduction}

As a pillar industry of the national economy, the problems existing in the development of the construction industry can be alleviated or even solved in the new round of industrial revolution, such as construction waste pollution, waste of resources and other practical problems.

The new development concept of high quality puts forward new and higher requirements for the development of China's construction industry ${ }^{[1-4]}$. At the same time, in the 40 years of China's reform and opening up, although the overall economic development has made many achievements, the problem of insufficient regional development imbalance is also very obvious. The same development problems also exist in the construction industry.Therefore, it is necessary to build a set of construction industry evaluation system under the background of the develop high quality, evaluate the the develop high quality level of the construction industry at provincial level.

\section{Construction of measurement system}

\subsection{Theoretical Basis}

Most academic circles believe that "economic growth" and "development quality" are two important aspects of high-quality economic development.In view of the close relationship between the industry and economic, studying the development quality of the construction industry will inject powerful impetus into China's economic development ${ }^{[5-8]}$. Therefore, the evaluation of the develop high quality level of construction industry can also be carried out from two aspects: "construction industry growth" and " quality of construction industry development".

The growth of construction industry is an important achievement of the rapid development of China's construction industry for more than 40 years, and it is also an important material basis for the construction industry. Summarizing the achievements of previous researchers, the growth of construction industry mainly includes the scale of construction industry.Growth and stability of construction industry growth. Under the current situation, the development brought about by the rapid expansion of the construction industry is becoming.In the new era, the connotation of the develop high quality of construction industry should not only include architecture

Industry growth, but also should highlight the development quality of the construction industry. In essence, "construction industry development quality" is the degree to which "inherent attributes" meet in the development process of construction industry.

"meeting needs" is a multi-dimensional concept, starting from the five development concepts, it is embodied in meeting innovative development needs, coordinated development needs, green development needs, open development needs and shared development needs. Therefore, this paper takes the five development concepts as the guiding ideology, refers to the construction of the high-quality economic development measurement system by scholars, and starts from the two angles of construction industry growth and development quality, and constructs the construction industry scale growth, growth stability, innovative development, coordinated development, green development, and so on.

\subsection{Construction Principles}

The construction of high-quality economic development measurement system mainly adheres to the following three aspects.

Principles:

(1) Systematic principle. The measurement index must be able to reflect comprehensively.

The economic and social factors, resources and environment of the construction industry, each evaluation refers to

(2) Scientific principle. The choice of index should

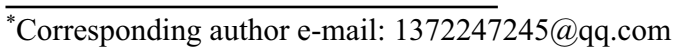


have the branch of theoretical system

Support, it is necessary to reflect the actual situation of the the develop high quality of the construction industry, but also have one.

\subsection{Measurement System and index Selection}

\subsection{1 innovation and development}

The first is to take innovation as an input factor from the perspective of the process, and measure its impact on the efficiency of other production factors, that is, the ability of innovation to improve efficiency. Second, from the perspective of results, measure the effectiveness of innovation, that is, the driving ability of innovation.

\subsection{2 coordinated development}

The the develop high quality of the construction industry puts forward higher requirements for the coordinated and balanced development of the industrial structure of the construction industry. The coordinated development of the industrial structure of the construction industry can be measured from three dimensions.

\subsection{3 green development}

As an important part of economic and social development, the construction industry is highly dependent on the environment and resources. Therefore, to achieve the develop high quality, the construction industry must establish and practice the green development concept of "green mountains and green mountains are Jinshan Yinshan".

\subsection{4 open development}

Openness and inclusiveness are the only way for the the develop high quality of China's construction industry. Under the new situation of further optimizing economic structure and expanding opening to the outside world, the open development of construction industry can be measured from two aspects: domestic opening and international opening.

\subsection{5 sharing development}

Sharing is the fundamental purpose of the develop high quality of construction industry. The the develop high quality of construction industry means the improvement of social welfare brought by construction industry:physical product distribution.

\subsection{Composition of Measurement System}

As shown in Table 1, this paper selects 24 indicators as the basic evaluation indicators of construction industry development under the background of the develop high quality.
Table 1 Development evaluation index system

\begin{tabular}{|c|c|c|c|}
\hline Primary & Secondary & Three-level & weight \\
\hline \multirow{4}{*}{$\begin{array}{c}\text { Innovative } \\
\text { development }\end{array}$} & \multirow{3}{*}{$\begin{array}{c}\text { Efficiency } \\
\text { improvement }\end{array}$} & Productivity & \multirow{4}{*}{0.1677} \\
\hline & & Technical & \\
\hline & & $\begin{array}{l}\text { Equipment } \\
\text { rate }\end{array}$ & \\
\hline & $\begin{array}{l}\text { Innovation } \\
\text { driven }\end{array}$ & $\begin{array}{l}\text { Total power of } \\
\text { construction } \\
\text { equipment }\end{array}$ & \\
\hline \multirow{7}{*}{$\begin{array}{l}\text { Coordinated } \\
\text { development }\end{array}$} & \multirow{2}{*}{ Scale structure } & $\begin{array}{l}\text { Foreign- } \\
\text { funded } \\
\text { enterprises }\end{array}$ & \multirow{7}{*}{0.2146} \\
\hline & & $\begin{array}{c}\text { State-owned } \\
\text { enterprises }\end{array}$ & \\
\hline & \multirow{2}{*}{$\begin{array}{l}\text { Organization } \\
\text { structure }\end{array}$} & $\begin{array}{l}\text { Supervision } \\
\text { institutions }\end{array}$ & \\
\hline & & $\begin{array}{l}\text { Contracting } \\
\text { enterprises }\end{array}$ & \\
\hline & \multirow{3}{*}{$\begin{array}{l}\text { Manpower } \\
\text { structure }\end{array}$} & $\begin{array}{l}\text { Personnel with } \\
\text { high } \\
\text { professional } \\
\text { titles in } \\
\text { institutions }\end{array}$ & \\
\hline & & $\begin{array}{c}\text { Supervision } \\
\text { engineer }\end{array}$ & \\
\hline & & $\begin{array}{l}\text { Bidding } \\
\text { technical } \\
\text { personnel }\end{array}$ & \\
\hline \multirow{5}{*}{$\begin{array}{c}\text { Green } \\
\text { development }\end{array}$} & \multirow{3}{*}{$\begin{array}{c}\text { Resource } \\
\text { consumption }\end{array}$} & Lass & \multirow{5}{*}{0.2913} \\
\hline & & Steel & \\
\hline & & Cement & \\
\hline & \multirow[b]{2}{*}{$\begin{array}{c}\text { Environmental } \\
\text { protection }\end{array}$} & $\begin{array}{c}\text { Daily sewage } \\
\text { treatment }\end{array}$ & \\
\hline & & $\begin{array}{c}\text { Green } \\
\text { coverage rate }\end{array}$ & \\
\hline \multirow{3}{*}{$\begin{array}{c}\text { Open } \\
\text { development }\end{array}$} & Domestic & $\begin{array}{c}\text { Output ratio of } \\
\text { private } \\
\text { enterprises }\end{array}$ & \multirow{3}{*}{0.1212} \\
\hline & opening & $\begin{array}{c}\text { Output ratio } \\
\text { outside the } \\
\text { province }\end{array}$ & \\
\hline & Opening abroad & $\begin{array}{l}\text { Proportion of } \\
\text { foreign } \\
\text { investment }\end{array}$ & \\
\hline \multirow{5}{*}{$\begin{array}{c}\text { Shared } \\
\text { development }\end{array}$} & $\begin{array}{l}\text { Entity product } \\
\text { allocation }\end{array}$ & $\begin{array}{c}\text { per capita } \\
\text { housing space }\end{array}$ & \multirow{5}{*}{0.2052} \\
\hline & Distribution of & $\begin{array}{l}\text { Average urban } \\
\text { wage }\end{array}$ & \\
\hline & $\begin{array}{l}\text { economic } \\
\text { welfare }\end{array}$ & $\begin{array}{l}\text { Business taxes } \\
\text { and surcharges }\end{array}$ & \\
\hline & \multirow{2}{*}{$\begin{array}{l}\text { Infrastructure } \\
\text { sharing }\end{array}$} & $\begin{array}{l}\text { Actual road } \\
\text { length }\end{array}$ & \\
\hline & & $\begin{array}{l}\text { City bridge } \\
\text { (seat) }\end{array}$ & \\
\hline
\end{tabular}

\section{Measure Method}

Entropy weight method can obtain more objective index weight, and reduce the interference of human factors to the greatest extent; TOPSIS method is simple in principle, can evaluate multiple objects at the same time, has high resolution and objective evaluation, and has good 
practicability and rationality.

a. Entropy weight TOPSIS method combines the advantages of both.

b. The specific steps are as follows: standardization treatment. Use formula (a) to standardize the measure index Xij.

c. In which I represents the measurement object and represents the measurement index.

$\mathrm{d}$. The measurement indexes of construction industry before and after standardization are expressed by Xij and Yij respectively.

e. Calculate the information entropy EJ of the evaluation index Yij.

$\mathrm{f}$. The weighted matrix of measure index is constructed. QJ.

g. Determine the best aspect Qj and the worst scheme

h. Euclidean ditances $\mathrm{d}$ and $\mathrm{d}$ are calculated.

i. The relative proximity $\mathrm{Ci}$ between each measure index and the ideal scheme is calculated, in which the larger the value of $\mathrm{Ci}(0<\mathrm{ci}<1)$ indicates.

The data in this paper comes from the provincial statistical yearbooks in 2018, the China Construction Industry Statistical Yearbook in 2018 and the China.

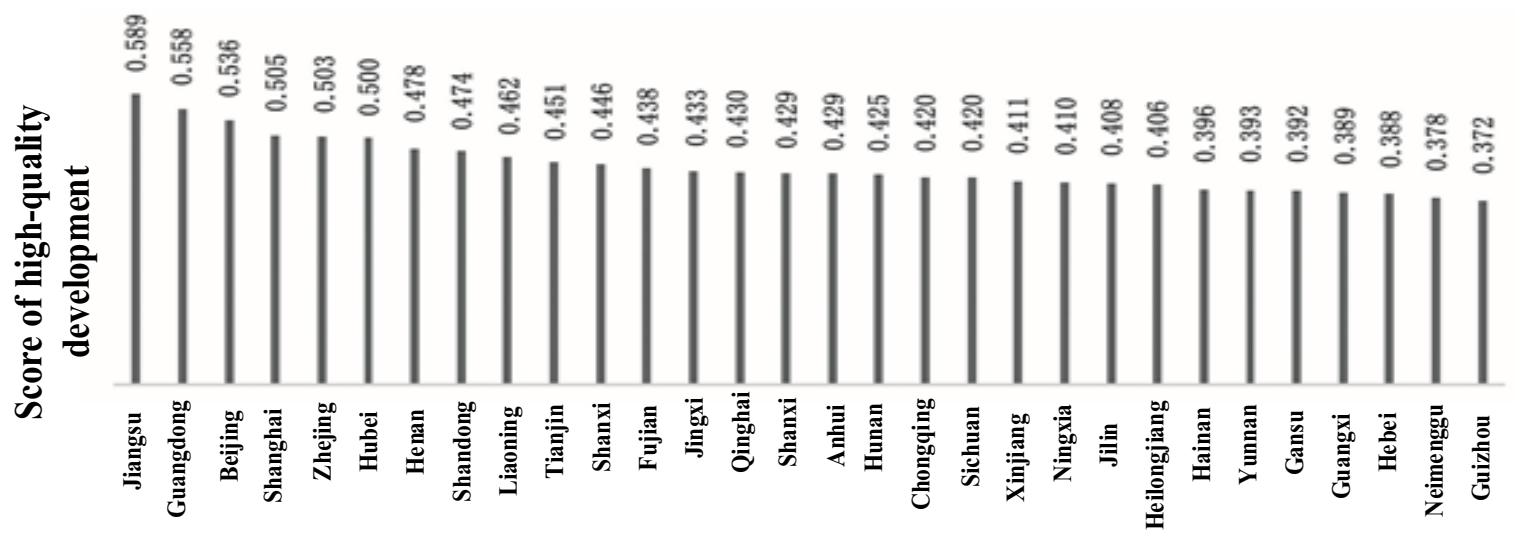

Figure 1 Comprehensive score of construction industry development in 30 provinces

\section{Analysis of development level}

In 2017 , the ranking of the develop high quality level of construction industry in China is shown in Figure 1. It can be seen from Figure 1 that Guizhou scored the lowest (0.372) and Jiangsu scored the highest (0.589). According to the relationship between the average score and standard deviation, it can be seen from Figure 1 that 30 provinces can be divided into three types: potential type (score greater than $\mathrm{M}+0.5 \mathrm{SD}$ ), general type (score between $\mathrm{M}$ $0.5 \mathrm{SD}$ and $\mathrm{M}+0.5 \mathrm{SD}$ ) and backward type (score lower than M-0.5SD).

Furthermore, the average score of the three regions was calculated and found that the average score of the eastern region was 0.482 , which was better than the national average. The comprehensive average scores of the central and western regions are 0.441 and 0.404 , which are behind the national average.

Table 2 Regional distribution of the develop high quality level of three types of construction industry

\begin{tabular}{|c|c|c|c|}
\hline Typeregion & east & midland & western part of the country \\
\hline $\begin{array}{c}\text { Potential } \\
\text { type }\end{array}$ & $\begin{array}{c}\text { Jiangsu, Shanghai, Beijing, } \\
\text { Guangdong, Zhejiang and Shandong }\end{array}$ & Henan and Hubei & \\
\hline General type & Liaoning, Fujian and Tianjin & $\begin{array}{c}\text { Hunan, Shanxi, } \\
\text { Jiangxi, Anhui }\end{array}$ & Sichuan, Qinghai, Shaanxi and Chongqing \\
\hline $\begin{array}{c}\text { Backward } \\
\text { type }\end{array}$ & Hainan and Hebei & Jilin, Heilongjiang & $\begin{array}{c}\text { Gansu, Guangxi, Inner Mongolia, Xinjiang, } \\
\text { Yunnan, Guizhou and Ningxia }\end{array}$ \\
\hline
\end{tabular}

Statistical Yearbook: Adjust the data with 2016 as the base period to ensure comparability between the data; Macao and Taiwan and Tibet, the above areas are not included in the measurement scope in this paper.

\section{Conclusions and suggestions}

\subsection{Conclusion}

Through the construction of high-quality building development measurement system of industry in 30 provinces of China in 2017:
According to the calculation of the measurement system, the average score of the develop high quality of China's construction industry is only 0.442 . Even the welldeveloped Jiangsu and Guangdong scored only 0.589 and 0.558 . The number of potential provinces is only 8 , and the rest are all general provinces and backward provinces .

\subsection{Suggestions}

Based on the above research, relevant suggestions and suggestions are put forward: 


\subsubsection{Suggestions on the low level of the develop high quality}

In view of the overall low level of the develop high quality of China's construction industry.Question, put forward the following five suggestions:

1) Improve the innovation. Encouragement fund Enterprises with high quality grades should strengthen cooperation with establish Enterprise R\&D center, promote the development and promotion of new technologies and new methods in construction industry Wide, constantly solve the problem of engineering construction, make it become the innovation .

2) Improve the coordinated development level of the construction industry. Further simplify administration, decentralization and expansion Open up, improve the scale and level of foreign capital utilization in construction industry; Establish a sound and reasonable work Cheng general contracting, construction general contracting, professional contracting. Powerful construction general contracting enterprises actively explore Transformation of general contracting enterprises, traditional supervision enterprises, engineering cost enterprises, etc. Explore the transformation to the whole process consulting enterprise.

3) Improve the green development level of the construction industry. Strengthen the control and management of environmental pollution in construction projects, vigorously advocate green and environmentally friendly buildings and prefabricated buildings, and reduce construction waste And the construction noise, dust and the like are obviously reduced; Establish and build Building energy conservation and emission reduction incentive mechanism, increasing the commitment to construction enterprises Financial subsidies.

4) Improve the open development level of the construction industry. Resolutely break the regional market Barriers, for local regulations that hinder the unified opening of the construction market.And practices will be cleaned up and abolished, creating a good construction market environment and promoting Free flow of production factors in construction industry; Building an effective construction industry "go" Go out "policy support system, support and encourage local enterprises to strengthen international cooperation .To expand the scale of foreign projects, relying on the national strategy of "the belt and road initiative", actively explore overseas markets.

5) Improve the shared development level of construction industry. Improve industry social security, establish and improve a long-term mechanism to prevent wage arrears of migrant workers, and rectify delays according to law Owning wages to migrant workers and safeguarding their legitimate rights and interests.

\subsubsection{Suggestions on uneven spatial layout}

In view of the regional differences in the the develop high quality level of the construction industry.Put forward the following suggestions.

Northeast China Revitalize the old industrial base and other national economic development strategies, and formulate regional interaction associations Adjust policies, improve experience exchange and interaction, and innovate and develop through market mechanism fruit space overflow and deepening the reform of "distribution suits" and promoting the creation of institutional mechanisms New and security aspects will comprehensively enhance the development of construction industry in all provinces, municipalities and autonomous regions Level, and finally realize the strong with weak, from point to area.

\section{References}

1. Qiusheng Tian. Theoretical connotation and practical requirements of high-quality development [J]. Journal of Shandong University (Philosophy and Social Sciences Edition), 2018 (6) :1-8.

2. Ying Sun. Promoting the high-quality development of green buildings [J]. Standardization of Engineering Construction,2018(11):28-31.

3. Long Xiu. Implementing the architectural policy in the new period to achieve high-quality development [J]. Architecture,2018(24): 20-22.

4. Zhang Yongheng. Study on the evaluation of highquality development in Henan Province from the perspective of five development concepts-based on entropy weight TOPSISI analysis method [J]. Henan Science, 2019(7):1187-1195.

5. Yangyue $\mathrm{Su}, \mathrm{Zhao} \mathrm{Miao}, \mathrm{Xu}$ Youquan, et al. Review of Industrial Structure of Construction Industry [J]. Project Management Technology, 2016 (9) :56-58.

6. Min Wei, Shuhao Li. Research on the Measurement of High-quality Development Level of Chinese Economy in the New Era [J]. Quantitative Economic, Technical and Economic Research,2018(11) : 3-20.

7. Zhongcheng Sun. Reform is the fundamental driving force for the high-quality development of the construction industry [J]. Architecture, 2019(6):2021.

8. Guiqing Lu. The road of high-quality development of construction industry in the new era $[\mathrm{J}]$. construction enterprisemanagement,2019(2):25-29. 